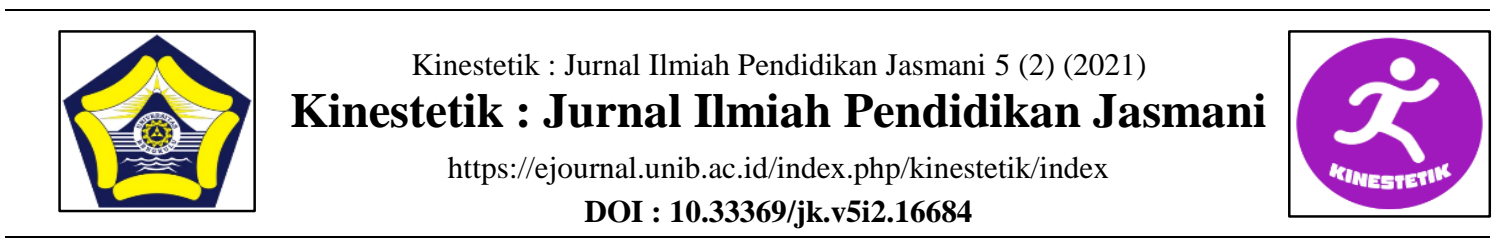

\title{
LEARNING RESULTS OF LONG BADMINTON SERVICES THROUGH THE COOPERATIVE STAD LEARNING MODEL
}

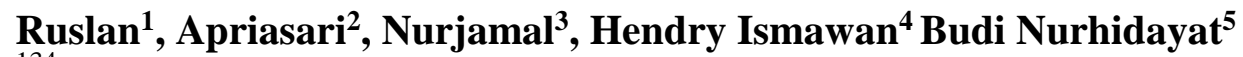 \\ ${ }^{134}$ Department of Teacher Training and Education, Universitas Mulawarman, \\ Samarinda, Kal-tim \\ ${ }^{2}$ Tenggarong Public Elementary School \\ ${ }^{5}$ First High School 13 Penajam
}

Article Info

Article History :

Received : June 2021

Revised : June 2021

Accepted : June 2021

Available online : June 2021

\section{Keywords:}

Learning Outcomes, STAD Learning Model, Long Service

\begin{abstract}
The service stroke is a technique with a racket that hits the shuttlecock to another field diagonally to start a game in badminton. In this service training in badminton uses the STAD cooperative learning model which emphasizes the existence of activities and interactions between students to motivate each other and help each other in mastering learning material. The purpose of this study is to improve learning outcomes forehand long service techniques using the STAD cooperative learning model. This type of research is classroom action research. The sample of 33 people was divided randomly into six groups. The research was conducted in II cycles, in one cycle two meetings. Data collection techniques in this study were documentation techniques, observation techniques and student learning outcomes tests that were given at the end of each cycle. The learning outcomes for two cycles using the cooperative learning model stad type in the long service technique for badminton forehand showed an increase in the average learning outcomes of each cycle, the percentage increase in the percentage from pre-cycle to cycle II was $11.30 \%$. The conclusion of this study is that using the cooperative learning model type STAD can improve learning outcomes for badminton forehand long service.
\end{abstract}




\section{INTRODUCTION}

Education is part of an effort to develop self-potential in order to grow into a human being who is strong and has character and has a healthy social life. Physical education is an integral part of total education which tries to achieve the goal of developing physical, mental, social and emotional fitness for the community, with a vehicle for physical activity Muhibin Syah, (2003: 213) states that "Learning outcomes are the mastery of relationships that are obtained so that someone can display the experience and mastery of the subject matter that has been studied. Learning outcomes are used to determine the extent to which students can understand and understand the material. According to Hamalik (2004: 31) learning outcomes are patterns of actions, values, knowledge, attitudes, appreciation, abilities, and skills. (Sukintaka, 2004). Learning outcomes are abilities that children get after going through learning activities, learning itself is a process of someone trying to obtain a form of behavior change that is relatively permanent (Jihad A and Haris A, 2013). In the physical education learning process, small games are taught, one of which is badminton. The badminton game is individual and is played singly and double by using a racket as a bat and the shuttlecock as an object that is hit and crosses the top of the net. Servis is the first stroke that starts a badminton game (James Poole, 2011). Servis according to Tohar, (1992: 40) in badminton is a racket that flies the ball / shuttlecock to another field diagonally and aims to open the game and is an important stroke in badminton, Alhusin, (2007: 33) argued that "In the rules of badminton games, service is the initial capital to be able to win the competition. The results of the researchers' observations, previous Physical Education learning used a method where students tended to be passive during questions and answers and student understanding was lacking and during practice students still made movements that were not in accordance with the instructions. resulting in low student ability to serve, especially the long forehand service. There are several factors, it can be seen that during the learning process there are still errors that occur in the racket handle, the shuttecock, racket swing and the position of the legs and it is found that students' behaviors are not good in the learning process such as students who do not respect their peers.

The STAD type learning model is that students are divided into learning teams consisting of four people with different levels of ability, gender and ethnic background. Emphasize activities and interactions among students to motivate each other and help each other in mastery of learning. So that students do not experience boredom in learning because students can motivate and support each other to solve a problem, provide solutions to each other and share experiences and be responsible for their respective groups (Slavin, 2016).

This research is expected to prove that the STAD type learning model can improve learning outcomes of badminton forehand long service techniques.

\section{METHODS}

This research is a Classroom Action Research (CAR) model, this research chooses the Classroom Action Research model of Suharsimi Arikunto, namely (1) Planning, (2) Implementation, (3) Observation, and (4) Reflection.

\section{Participants}

The research was conducted at the Mts Al-Masyhuriyah Tenggarong School across from March-April 2019. The samples in this study were boys and girls 
in grade VIII 1. The total sample size of this study was 33 people divided into six groups with 5-6 people each. Each group gets student worksheets with the form of service exercises that vary for each group. Students were given treatment for 4 weeks and 2 cycles with a frequency of 1 time a week. Data collection techniques in this study are documentation techniques, observation techniques and test techniques (Suharsimi Arikunto, 2006).

\section{Procedures}

This study chose this research to choose the Classroom Action Research model of Suharsimi Arikunto, namely (1) Planning, (2) Implementation, (3) Observation, and (4) Reflection. Research procedures based on the Classroom Action Research model in the form of a cycle are as follows:

\section{Cycle I}

\section{Planning (planning)}

In this stage the researcher prepares everything that is needed in the research, including the following:
a. Analyzing the curriculum used by the school to determine the standard of competence that will be delivered to students
b. Prepare a Learning Implementation Plan (RPP)
c. Prepare all the equipment needed in research
d. Prepare observation sheets.

\section{Implementation (Acting)}

In this stage the researcher takes action / treatment that will be carried out during learning activities at MTS Al-Masyhuriyah Tenggarong Seberang by involving students directly, in order to discuss learning in accordance with the theme. With the learning process not only in the classroom or in the classroom environment, but also outside the classroom. At the first meeting, the learning process was carried out using the STAD cooperative learning model with Badminton forehand Long Service Material which was carried out according to the scenario that was designed in the Learning Implementation Plan (RPP), and the second meeting was carried out tests and scoring according to the scenario that was designed in the Plan Implementation of Learning (RPP).

\section{Observation}

1) Conducting observations on the learning process carried out by the observer

2) Making observations on the aspects of attitude (affective) during the learning process carried out by the researcher

3) Conducting observations through test giving essay questions / multiple choice or essays (cognitive)

4) Observing the aspects of skills (psychomotor) by the observer.

\section{Reflection}

This activity begins by examining the results obtained from the results of research observations in cycle I, so that we can find out whether the STAD type of cooperative learning model can help develop the abilities of students in Badminton Forehand Long Service and decide to continue the cycle or stop the cycle.

\section{Data Analysis}

The analysis of the data from the results of this study is quantitative analysis, which is the analysis used to measure the increase in student learning outcomes as the effect of each action given, in managing and interpreting data through the following stages: 1. data reduction, 2. data presentation: in presenting data, it can be calculated by calculating the percentage, average 
(Sudjana, 2017) and diagrams, 3. Giving conclusions and 4 . Success indicators.

\section{RESULT}

In pre-cycle observations, students of class VIII 1 who succeeded in achieving the KKM score of the total 33 students were only $18.20 \%$ or six students and $81.80 \%$ or 27 students who had not reached the KKM score with an average of only 70.24. The results of learning the forehand long service technique on students of MTs al-masyhuriyah Tenggarong opposite showed an increase from the first cycle to the second cycle.

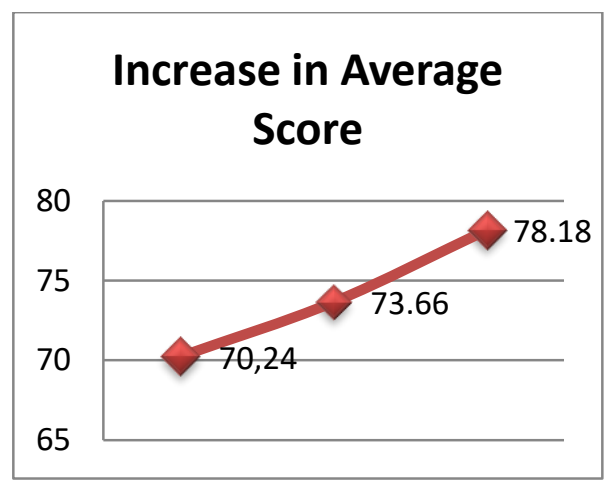

Figure 1. Increase in the Average Score of Students

The KKM value that has been set by the school is 75.00 in physical education learning. KKM or $48.50 \%$ and 17 students have not reached the KKM score. In cycle two students are more given treatment by improving racket swing and shuttlecock accuracy when serving, in cycle two

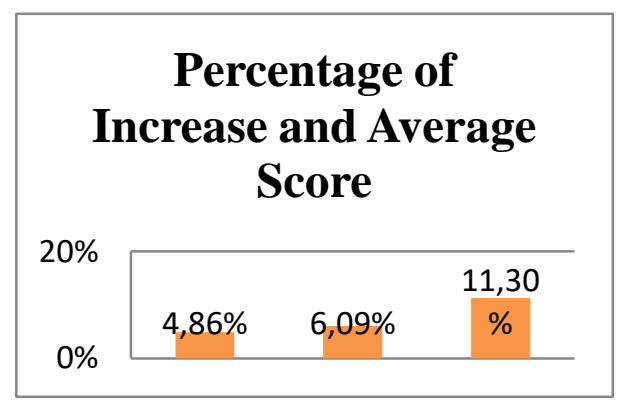

Figure 2. The percentage increase in the average score of students

\section{DISCUSSION}

This study involved all students in that class. The problem that was found before being given the action was the average score of students who were still below the Minimum Completeness Criteria (KKM), which was 75 . From the KKM score in the pre-cycle students who achieved completeness were 6 students and those who did not complete were 27 students. students in learning do not respect colleagues in learning, as well as in the implementation of servicing the position of the body, feet and hands is not quite right. Here the researcher uses the STAD type cooperative learning model. STAD is (Division of Student Team achievement) According to Slavin (2016: 11) In cooperative learning type STAD emphasizes the existence of activities and interactions between students to motivate each other and help each other in mastering the subject matter. So that with the STAD cooperative learning model, students do not experience burnout in learning because students can support and motivate each other to overcome a problem at hand, provide solutions to one another, share experiences and be responsible for their respective groups. In STAD learning is to motivate students to support and help each other in mastering the skills taught by the teacher (Gunarto: 2013), students are divided into several groups, then when learning takes place so that students get the value they want to achieve, students must really listen and be able to work together when in a team. In carrying out long forehand services it is divided into three phases, namely the preparation phase, the implementation phase and the followthrough phase in the preparation phase where students use the forehand grip, stand with one leg apart, one in front and one behind, leaning on the hind leg and the hand holding it. racket in the backswing position according to (Tony Grice: 2004). 
Then in the exercise phase, the body weight is transferred, hands are bent over and wrists are jerked and the shuutlecock box is at knee height. In the final followthrough phase with the racket pointing straight up, then cross the racket over the shoulder of the non-racket hand and rotate the hips and shoulders. The results of the research in the first cycle of students who completed were 16 students who completed and students who did not complete were 17 students, there were still many students who came late, students who were less orderly, did not respect their peers.

Cycle 1 cognitive aspects of the teacher provide action by giving learning sheets to each group and conveying the history of the Badminton game the results expected by the researcher regarding the extent of students' knowledge of badminton and the extent to which students understand the concept of badminton and understand the long service procedure for badminton forehand. still lacking after reflecting, the researcher found several causes, namely the teacher was still not using good and fluent language, the teacher's explanation was not clear, and the learning situation was less conducive.

The psychomotor aspect of the teacher provides action in the form of 2 kinds of exercises, namely by performing a long forehand service without using a shuttlecock. swinging the racket and falling the shuttlecock must be at the same time, so at the beginning of the first cycle the researcher used service training without using the shuttlecock, the aim was that students relax in swinging the racket and get used to students so that they are no longer stiff in serving and the form of forehand long serve training using the shuttlecock. However, during the implementation of cycle I, there were still students who did not understand how to do the correct forehand long service, the body position was not ready and not relaxed, the ball was not right because the racket handle used was not the forehand grip, and the position of the legs was not on front and one behind and not bent. Therefore, the researcher felt the need to proceed to cycle II with some notes that had to be improved, starting from using spoken language correctly and fluently, giving sanctions so that students were more disciplined. Based on the analysis carried out in cycle I, the research decided to continue the research into cycle II.

The results of the research in the second cycle experienced an increase in the affective, cognitive, psychomotor aspects. Researchers compiled a learning plan in accordance with the results of the reflection of cycle I and tried to apply it as well as possible to the affective aspects which in cycle I there were many disciplinary violations in the form of arriving late, not being able to cooperate in the learning process between fellow groups and not appreciating fellow friends in the second cycle. II can no longer be seen, students arrive on time, are able to work together and respect their peers. Researchers assessed that sanctioning was a factor that influenced a significant increase in the percentage of students' affective values in addition to the provision of rewards in stad type learning

Cognitive aspects, the value of students also experienced an increase, which in the previous cycle, namely cycle I, there were still some students who had not yet completed it and there were still many students who had not fulfilled the expectations of researchers in the form of knowledge of badminton games and understanding of the concept of badminton in cycle II. It encourages students not only to have good knowledge but also good understanding of badminton forehand long service concepts and procedures. The researcher assessed this was due to the first several factors the researcher used good and fluent language, better explanation of 
the material by the researcher so that students could understand more, and was supported by a conducive learning situation and the questions given in cycle I and cycle II were not much different.

The psychomotor aspect in cycle II the teacher provides action in the form of 2 types of training, namely with a circle formation by means of implementation, namely one student stands in the middle of the circle to be an example in implementation, here the student swings the racket from behind right then returns to the left and so on. like forming a figure eight, the purpose of this swing is as stated by James Poole (2013: 24) that the swing of the racket and the drop of the shuttlecock must coincide. Here students practice swinging the racket again so that the service is not stiff and the swing of the racket and the accuracy of the fall of the ball together in order to produce a high serve and is far behind the back line of the student and the second exercise is serving with two lines when practicing students have started to understand how to do the correct forehand long serve, the body position has started correctly, the ball is right on the racket so that it can serve properly, and the position of the legs has started to take turns making it easier for students to maintain balance. There are students who have begun to understand how to perform long forehand services, body position has begun to improve, then the ball has started right on the racket, the position of the footstool is replaced and bent and the legs are opened shoulder width apart.

This increase occurred because the application of the STAD cooperative learning model has given a good impression to students, namely students who understand more about badminton forehand long service skills can help their group mates and can work together in one team (group) until one group is declared successful or successful. complete in following the learning process of badminton forehand long service.

Overall, the learning outcomes data from cycle I to cycle II have increased from 73.66 to 78.18 if this increase is a percentage, then the result of this increase is $6.13 \%$. and the overall cycle, namely pre-cycle, cycle I to cycle II has increased from $70.24,73.66$ to 78.18 or an increase of $11.30 \%$ and the researcher decided not to continue to the next cycle, because the students' scores from pre-cycle to cycle II has increased. With this it can be concluded that the cooperative model type STAD can improve learning outcomes in class VIII 1 students of MTs AlMasyhuriyah Tenggarong Seberang.

\section{CONCLUSION}

STAD type learning model can improve learning outcomes of badminton forehand long service techniques. By using the STAD type learning model students do not experience boredom during learning, motivate each other in groups, support each other, work together in overcoming a problem faced and a sense of responsibility arises towards their groupmates As well as giving rewards to superior groups as well as getting students to work together in teams and teaching group members who have not been able to do forehand long service, so that all group members can and are actively involved in learning.

\section{REFERENCES}

A.Wijaya, (2017) Analisis Gerak

Keterampilan Servis Dalam Permainan Bulutangkis (Suatu Tinjauan Anatomi, Fisiologi, Dan Biomekanika), Indonesia Performance Journal, 1(2) 1060111

Debbi, Ariyandhi (2015).Pembelajaran Servis Panjang Dalam Permainan 
Bulutangkis Melalui Modifikasi Raket Kayu , Jurnal Active Vol 4 (10) ; 2112-2116.

Hermawan Aksan. (2013). Mahir Bulutangkis. Bandung : Nuansa Cedekia

Jihad, Asep \& Haris, Abdul. (2013). Evaluasi Pembelajaran. Multi Pressindo.

Kholison, F., \& Defliyanto, D. (2018). Pengaruh Latihan Drill Terhadap Kemampuan Servis Backhand Bulutangkis Siswa Mts Tarbiyah Islamiyah Kecamatan Air Napal Bengkulu Utara. Kinestetik: Jurnal Ilmiah Pendidikan

Kusmawan, Made Sudik. 2010. Implemantasi Model

Pembelajaran Kooperatif Tipe Student Teams Achievement Division (Stad) Untuk Meningkatkan Aktivitas Dan Hasil Belajar Teknik Pukulan Service Bulutangkis Pada Siswakelas Ix.A Smp Saraswati Singaraja Tahun Pelajaran 2010/2011.Singaraja: Jurusan Pendidikan Jasmani Kesehatan Dan Rekreasi, Fakultas Olahraga Dan Kesehatan, Universitas Pendidikan Ganesha

Poole, James. (2013). Bulutangkis. Bandung: Poinir Jaya.

Purnama, Sapta K. 2012. Kepelatihan Bulutangkis Modern. Surakarta: Yuma Pustaka.

Pujianto, A. 2012. Modifikasi Pegangan Raket Untuk Meningkatkan Kemampuan Teknik Pegangan Bulutangkis. Media Ilmu Keolahragaan Indonesia, 2(1). Http://Journal.Unnes.Ac.Id/Nju/In dex.Php/Miki/Article/View/2548.

Diakses 5 Mei 2021

Sadik (2016). Upaya Meningkatan Keterampilan Dribbble Bola Dalam Permainan Sepak Bola Dengan Metode Student Teams
Achievement Division Pada Siswa 1 Pemekasan , Jurnal Sportif Vol 2 (1) ; 87-92.

Stephani Yanae (2016). Peningkatan Servis Panjang Bulutangkis Melalui Model Problem Based Learning , Jurnal Pendidikan Olahraga Vol 5 (2) ; 165-174.

Slavin, E. Robert. (2015). Cooperative Learning. Nusa Media.

Sudjana, Nana. (2017). Penilaian Hasil Proses Belajar Mengajar. Bandung : Pt. Remaja Rosdakarya.

Sudijono. 2014. Pengantar Statistik Pendidikan. Jakarta: Pt. Raja Grafindo Persada.

Syah, Muhibbin. 2010. Psikologi Pendidikan Dengan Pendekatan Baru, Bandung:Remaja Rosdakarya

Jupri, Ruslan, Rahmadi (2020) The Influence Of Forehand Grip Handling And Backhand Grip On Short Service Ability In Badminton Of Collage Students Jurnal Kinestetik : Volume 4 No 2. 2020

Tamim, M. H. 2017. Pengaruh Metode Latihan (Resiprokal Dan Inklusi) Persepsi Kinestetik Terhadap Teknik Overhead Lob Forehand Bulu Tangkis. 